Potravinarstvo Slovak Journal of Food Sciences

vol. 15, 2021, p. 162-172

https://doi.org/10.5219/1511

Received: 17 November 2020. Accepted: 29 January 2021.

Available online: 28 March 2021 at www.potravinarstvo.com

(C) 2021 Potravinarstvo Slovak Journal of Food Sciences, License: CC BY 4.0

ISSN 1337-0960 (online)

\title{
THE STUDY ON THE PROCESS OF DEHYDRATING LEGUMES DURING HIGH-TEMPERATURE MICRONIZATION WITH INFRARED RAYS
}

\author{
Otari Sesikashvili, Nodari Mardaleishvili, Elene Gamkrelidze, Shalva Tsagareishvili
}

\begin{abstract}
Heat treatment is a common operation in grain processing technology. Thermal action on grain is characterized by temperature level and duration. Also, the grain changes all its complex properties. Frequently, the temperature in grain activates the process of change in the moisture content and is accompanied by moisture loss. The processes of change in the heat and moisture are interrelated. Based on the experiments conducted on legumes (different varieties of bean, white lupin), a mathematical model of these processes has been developed and the appropriate non-linear differential equations have been used. The obtained equations cannot be solved either analytically or numerically, because some of the coefficients are unknown. The equations are solved based on certain assumptions. Based on these assumptions, the paper provides the calculation of the change in temperature and moisture content over time in legumes, such as bean and white lupin. The obtained results have been compared with experimental data.
\end{abstract}

Keywords: IR radiation; heat treatment; bean; legume grain; dehydration; moisture content

\section{INTRODUCTION}

The heat treatment, in particular, with the use of the radiation (infrared) energy input, is a fairly common operation in the grain processing technological processes. This is the method that is most frequently used by large enterprises producing instant cereals and cereal flakes and is known as high-temperature micronization (Zverev, 2009). In the production of grain products, many methods of heat treatment (HT) of grain have been proposed, such as roasting, steaming, extrusion, micronization, etc. (Zverev, Sesikashvili and Bulakh, 2017). In any case, the process is associated with the rising temperature of the product within a certain time interval. The use of electromagnetic radiation for heating and heat treatment of products is based on the phenomenon of the absorption of radiation incident on the product and conversion of its energy into heat (Rogov and Nekrutman, 1986). When producing products from legumes, it is economically feasible to use heat-treated fullfat soybeans in livestock feeding. It has proven to be difficult to cut the cost of these products in other ways (Shulaev and Betin, 2010). Since the unwanted components in soy are thermolabile components, it is acceptable to process them in a relatively inexpensive waysuch as the thermal method, to increase the nutritional value of the soybean and to inactivate the unwanted components (Perez-Maldonado, 2002). During the heating process, the product is dehydrated. The temperature and final moisture content of legumes during heating by infrared (IR) radiation are determined by several factors: heating time, initial moisture content of beans, and heat treatment conditions (irradiance, the ambient tempera-ture in the working area) (Zverev and Sesikashvili, 2018). Usually, these conditions in industrial facilities are dependent on their designs and rarely change during operation, even if this possibility exists. Moisture source raw material depends on its condition when delivered, storage conditions and can vary, sometimes widely. The outlet temperature of the product is regulated by its residence time in the working area (Zverev and Sesikashvili, 2018). The heating process, as a rule, is carried out under a high thermal head and is limited to the time when the grain surface begins to darken. The product temperature changes continuously throughout the entire period of treatment that is the process is essentially nonisothermal (Lykov and Mikhailov, 1972).

This work aimed to determine the experimental relationships and develop a model of heating legumes while varying moisture, irradiance and the ambient temperature in the heat treatment zone of infrared heating installations for legumes, as well as to establish the optimal heat treatment conditions to improve the nutritional value of legumes.

\section{Scientific hypothesis}

There is a correlation dependence of moisture content on the temperature of the product, as well as the influence of the above-listed factors on it. The temperature and final moisture content of legumes during heating by infrared (IR) radiation are determined by several factors: heating time, initial moisture content of beans, and heat treatment conditions (irradiance, the ambient temperature in the working area). 


\section{MATERIAL AND METHODOLOGY}

During experiments for heat treatment (HT) of the grain, a QP1 model (Elcer, Odesa, Ukraine) panel for halogen quartz emitters was used as a source of infrared (IR) radiation (see Figure 1). The dimensions of a panel for quartz emitter were $62 \times 247 \mathrm{~mm}$, rated power $\mathrm{W}=1 \mathrm{~kW}$, emitter temperature $750{ }^{\circ} \mathrm{C}$.

By the nature of the structural design of the heat treatment zone, along with radiation heat exchange, convective heat transfer occurs between pulse product and air, while the convective heat transfer is more intense, the higher the temperature in the working area. The upper limit of this temperature is determined by the technical capabilities of the structural elements.

The ambient temperature in the heat treatment zone is included in all mathematical models of the heating process. Moreover, in several works, it was assumed that this temperature is proportional to the irradiance, $\Delta \mathrm{T}_{\mathrm{c}}=\mathrm{K}_{\mathrm{c}} \mathrm{E}$, which required experimental verification.

The possibility to change the emitter height $h_{l}$ above the product allowed to vary the irradiance.

The linear dimensions of the bean were determined using an electronic digital caliper VINCA DCLA-0605 Electronic Digital Caliper, $150 \mathrm{~mm}$. (AMAZON.CO. UK, Tbilisi, Deliver to Georgia).

The surface temperature of the sample-weight of beans was measured under the middle lamp of the emitter was determined as follows: the bean was arranged on the pallet in a monolayer, which, for a fixed amount of time $(30,60$, 90 , and $120 \mathrm{~s}$ ) was placed in a heated IR treatment zone. Then the pallet was quickly removed and the temperature of beans was determined using an AR360A+ infrared laser thermometer (IntellSafe, Shenzhen cheerman technology CO., LTD, Guangdong, China), the temperature measurement interval was $-50-+360^{\circ} \mathrm{C}$, and the accuracy was $0.5^{\circ} \mathrm{C}$ Error in the temperature due to heat loss when the bean moves from the treatment zone to the measurement area is insignificant.

The temperature inside the beans was determined using a thermocouple with a wire diameter of $0.1-0.2 \mathrm{~mm}$, which was connected to a DT 9208A (ANENG, Nanchang Huatuo Industrial Co., Ltd. China) digital multimeter (the temperature measurement range was $-40-+1370{ }^{\circ} \mathrm{C}$ ) (see Figure 2). To that end, the grain was drilled through until its midpoint with a drill $1 \mathrm{~mm}$ in diameter, and then a thermocouple was inserted. The temperature was recorded every $30 \mathrm{~s}$. To minimize the effect of direct radiation on the readings, the thermocouple was placed in a tube made of a material with a reflection coefficient of $\mathrm{R}=0.9$ in a wavelength range of $\lambda=1 \mu \mathrm{m}$.

The initial moisture content of grain was determined using an electronic digital meter of grain and seed moisture (moisture meter) VSP-100 (Proautotools, Kharkiv, Ukraine).

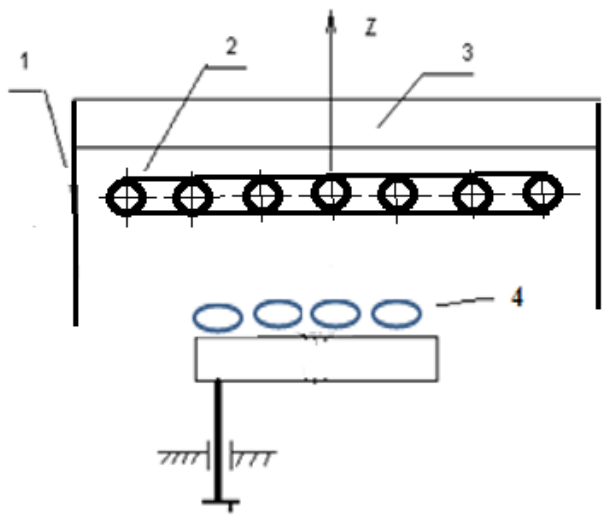

Figure 1 Scheme for (The IR panel QP1-type) measuring the temperature of a monolayer of beans: 1 - Lateral reflective screens; 2 - block of emitters; 3 - Upper reflective screen; 4 - Monolayer of beans on a stage.

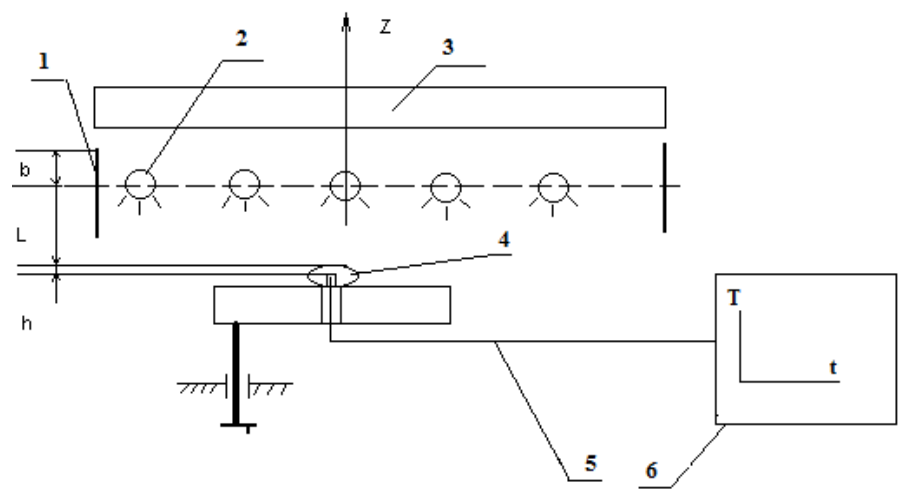

Figure 2 Temperature measurement design of a single bean: 1 - The lateral reflecting barriers; 2 - A QP1 model IR linear generator; 3 - An upper reflecting barrier; 4 - A bean on the object stage; 5 - Thermocouple (Ni-Cr, Ni-Al); 6 - The registering device. 
The moisture loss during IR heating was estimated as the difference between the initial sample weight and its weight after heat treatment.

The sample weight of the bean before and after heat treatment was determined using an SF - 400C (Banggood, China, Kyiv, Deliver to Ukraine), model electronic digital analytical balance, with a weighing accuracy of $0.01 \mathrm{~g}$. The moisture content $(\%)$, after heat treatment, was calculated based on the initial moisture content and mass loss according to the formula derived by prof. Zverev based on GOST 13586.5 (2015) and ISO 3166 (2015).

$$
\mathrm{W}=100\left[\mathrm{~W}_{0} / 100-\Delta \mathrm{m} / \mathrm{m}_{0}\right] /\left[1-\Delta \mathrm{m} / \mathrm{m}_{0}\right]
$$

Where:

$\mathrm{W}_{0}$ - initial moisture, \%; $\mathrm{m}_{0}$ - initial sample weight, $\mathrm{g} ; \Delta \mathrm{m}$ - sample weight loss, g.

\section{Statistical Analysis \\ Non-linear modeling was carried out by using an application software package "STADIA-6", developed at the M. V. Lomonosov Moscow State University Kulaychev (1999). Scoping the adequacy of the models is a complex procedure, requiring high computational costs, which are rapidly growing with dimensions of space of external parameters. By the volume, this task may greatly exceed the task of parametric optimization of a model itself (especially in the case of a nonlinear model), that's why for the newly- designed objects, it may not be resolved. Some indication of the adequacy of the models is provided by the squared multiple correlations, $\mathrm{R}^{2}$. To describe the ordered sample, we used statistical functions of the average arithmetic value and the average standard error. We selected the value of reliability $p<0.05$.}

\section{RESULTS AND DISCUSSION}

The author recommends the method of high-temperature micronization (HTM) - heating in infrared fluxs for the heat treatment of food products and legumes to obtain products with a higher nutritional value (Zverev, 2009; Pan and Atungalu, 2010). The author provides data obtained during heat treatment of soybeans in a laboratory facility with infrared (IR) emitters KGT-220-1000 (Zverev and Kozin, 2008). The authors consider the method of high-temperature micronization (HTM) - heating in an infrared stream to obtain functional food products and increased shelf life (Zverev and Zvereva, 2006). Infrared (IR) heating provides significant advantages over conventional heating, including reduced heating time, uniform heating, reduced quality losses, absence of solute migration in food material, versatile, simple, and compact equipment, and significant energy saving. Infrared heating can be applied to various food processing operations, namely, drying, baking, roasting, blanching, pasteurization, and sterilization Lee (2020). The authors (Pan, Venkitasamy and Li, 2016) note that Infrared heating is used on an industrial and pilot scale for baking (roasting), drying, defrosting, pasteurizing, blanching, and peeling. For each of these operations, infrared heating equipment is either being used commercially or is currently in pilot development. We use infrared radiation to improve the nutritional value of legumes. The authors Žilić et al., (2009) argue that micronization of corn (at a temperature of $140^{\circ} \mathrm{C}$ within 40 s) did not affect the standard chemical composition flour from white, yellow, and red grains to a large extent. However, a slight decrease in ash, protein, and cellulose content was found in micronized red corn flour. Crude protein changes the content was insignificant, reduced solubility of some fractions indicated changes in the structure of the protein. Micronization negatively affects biologically active compounds (tocopherols, b-carotene) is natura $\neg$ lly found in raw grains. This thermal process increased antioxidant activity and changed the pastel properties of the selected corn flour samples. Due to the reduced POD levels in micronized flour samples are expected to be increased storage stability. Despite the modified diet and technological characteristics, micronized flour is a good raw material for gluten production-free products. The authors note Arntfield et al. (1997) the use of micronization (infrared treatment) on grain legumes tempered with water has the potential for reducing cooking times. Using Laird lentils, the effects of tempering conditions and moisture content following micronization were evaluated in terms of color, chemical properties, and texture after 15 min cooking. The texture of cooked lentils softened as tempering moisture increased. This was related to increasing starch gelatinization and decreasing protein solubility during micronization. IR heating for food and agricultural processing holds great potential for improved processing efficiency and product quality. The significant attractive merits of IR heating over conventional heating methods for various food-processing applications include high heat delivery rate, no need for heating medium, reduced processing time, improved energy efficiency, and enhanced product quality and safety without the significant negative environmental footprint. Selective heating can result in higher-quality food products that are safe for consumption (Pan and Li, 2014). The authors confirm that a simple infrared system consists of an emitter, which is a heat source (infrared lamp) and a reflector (used for temperature control). The efficiency of infrared equipment mainly depends on the type of heat source used. The emitter determines the color of the light, the wavelength of the process radiation, the process temperature, and the power density. Electric and gas heaters are commonly used for process heating (Vaidyanathan and Krishnamurthy 2020). The described IR equipment converges to our installation. The authors note Niu, Classen and Scott (2003) that five experiments were conducted to study the effects of micronizing, tempering, and flaking of wheat (cv. Genesis) on the chemical characteristics and its feeding value for broiler chicks. Samples of wheat were micronized (an infrared invisible band with wavelengths of 1.8 to $3.4 \mu$ ) at 90,105 , and $120{ }^{\circ} \mathrm{C}$ for $50 \mathrm{~s}$, with or without tempering to $20 \%$ moisture, and with or without flaking. Micronization at $120^{\circ} \mathrm{C}$ produced negative effects on weight gain and feed efficiency $(0-18$ days $)$. Tempering reduced protein solubility in $0.2 \% \mathrm{KOH}$, increased the solubility of dietary fibre, and increased in vivo digesta viscosity and in vitro extract viscosity as well as diet AME. Flaking wheat did not affect broiler performance in experiments 3 and 4, but decreased growth rate and feed efficiency in the experiment. The authors note that IR heating has demonstrated the advantage of efficient heat transfer to food products by reducing processing time and energy costs. The major obstacles to the adoption of most IR technologies in the food 
industry are the lack of in-depth understanding of IR heating fundamentals and the capital cost required in the initial setup by replacing the existing conventional processing equipment Erdoğdu et al. (2011). The authors note Kayitesi et al. (2013) that background cowpea is mostly utilized as cooked whole seeds. This is often achieved only after boiling for up to $2 \mathrm{~h}$, resulting in high energy consumption and a long time for food preparation. Micronisation of pre-conditioned cowpeas reduces their cooking time. Micronisation changes the physicochemical properties of cowpea seeds, which may affect the sensory properties of cooked cowpeas. Consumer acceptance and utilization of micronized cowpeas depend on their sensory properties. The authors (Ogundele and Kayitesi, 2019) emphasize the importance of using infrared heating as a method of shortening the cooking-time of African legume seeds and flour, by increasing their water absorption rates and pasting viscosity is emphasized in the literature. Structural changes caused by infrared heating of moistureconditioned African legumes include microstructural, molecular, and interaction of the biomolecules in the seeds.

The authors Sakare et al. (2020) provide a critical discussion of the principle, applications, and comparative performance of IR energy for drying a range of food materials including grains, fruits, vegetables, and seafood in the recent past. The effects of process variables on energy consumption, drying time, rate of drying, and quality of the dried product are explained in detail.

Using animal food with lupine, the authors Tuśnio et al. (2020) note that the animals fed diets with high lupin levels had significantly smaller bodyweight gain $(p=0.001)$ than those fed diets with low lupin level aside from the micronizing process.

The authors provide also comparative data on the effectiveness of one or another method of heat treatment of legumes. It has been established that the efficiencies of thermo--wet, infrared, and extrusion treatment in the final result are comparable - it's all a question of the cost price (Shurchkova, Ganzenko and Radchenko, 2007).

The authors claim that the treatment method significantly affects the level of exchange energy (including due to the inactivation of anti-nutritional substances). For example, if raw soybeans have an exchange energy level of 13.5 MJ. $\mathrm{kg}^{-1}$, then after wet extrusion the level of exchange energy for chickens is $17.9 \mathrm{MJ}_{\mathrm{kg}}{ }^{-1}$, dry extrusion 17.4 MJ. $\mathrm{kg}^{-1}$, micron-zation $-15.4 \mathrm{MJ} . \mathrm{kg}^{-1}$ and for roasting - $\quad 15.6 \mathrm{MJ.kg}^{-1}$ (Shershunov, Cherviakov and Kurzenkov, 2004).

The paper describes the method of heat treatment with a radiation energy supply (high-temperature micronization or IR heat treatment), the main directions of heat treatment of legumes and cereals have been determined. The hightemperature micronization with IR rays has been adopted as a major method Kozin (2011).

The measurement of the temperature and moisture content of grain was done at three levels of the height of the emitters set above the monolayer of grain $(100 \mathrm{~mm}, 75 \mathrm{~mm}$, and $50 \mathrm{~mm}$ ) and at three values of the initial moisture content. The experimental results are presented in Tables 1-3.

\section{Changes in the temperature of beans during the} process of IR heat treatment

The influence of the length of exposure of IR heat treatment on the temperature increment of the sample weight of the „Tsanava“ bean variety at the emitters' panel height of $100 \mathrm{~mm}$ is shown in Figure 3.

Influence of the length of exposure of IR heat treatment on the temperature increment of the sample weight of the "Tsanava“ bean variety at the emitters' panel height of $75 \mathrm{~mm}$ is shown in Figure 4.

The influence of the length of exposure of IR heat treatment on the temperature increment of the sample weight of the „Tsanava“ bean variety at the emitters' panel height of $50 \mathrm{~mm}$ is shown in Figure 5.

The results obtained are in good agreement with the results obtained for soybeans and cereals in the work Kozin (2011).

The authors (Semwal and Meera, 2020) investigated the change in the properties of grain starch when exposed to infrared radiation.

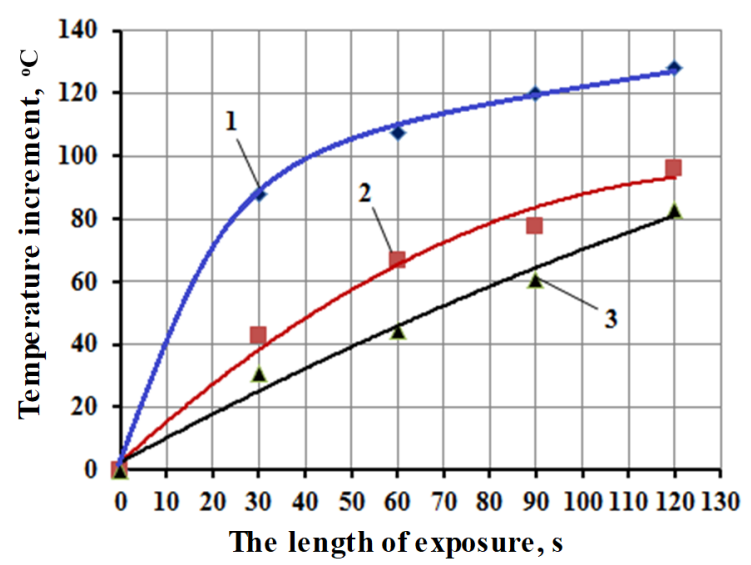

Figure 3 The influence of the length of exposure of IR heat treatment on the temperature increment of the sample weight of „Tsanava“ bean variety at the height of $100 \mathrm{~mm}$ from the QP1 model emitters set to the pallet, with the initial average moisture contents, $\%: 1-12.7 ; 2$ $-17.7 ; 3-29.2$.

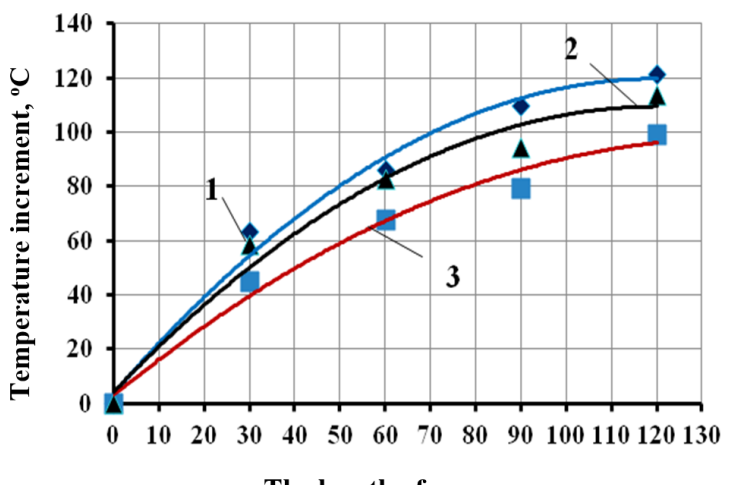

The length of exposure, $s$

Figure 4 The influence of the length of exposure of IR heat treatment on the temperature increment of the sample weight of ,Tsanava“ bean variety at the height of $75 \mathrm{~mm}$ from the QP1 model emitters set to the pallet, with the initial average moisture contents, $\%: 1-12.7 ; 2$ $-17.7 ; 3-29.2$. 
Table 1 ,Tsanava“ bean variety.

\begin{tabular}{ccccc}
\hline $\begin{array}{c}\text { Time, } \\
\text { Sec }\end{array}$ & $\begin{array}{c}\text { Initial temperature, } \\
{ }^{\mathbf{0}} \mathbf{C}\end{array}$ & $\begin{array}{c}\text { Initial moisture content } \\
\mathbf{W \%}\end{array}$ & $\begin{array}{c}\text { Final temperature, } \\
{ }^{\mathbf{C}} \mathbf{C}\end{array}$ & $\begin{array}{c}\text { Final moisture content, } \\
\mathbf{W} \%\end{array}$ \\
\hline 0 & 30.4 & 18.5 & 30.4 & 18.4 \\
30 & 30.5 & 18.6 & 73.4 & 14.4 \\
60 & 29.8 & 17.0 & 96.3 & 16.9 \\
90 & 30.4 & 17.1 & 108.1 & 16.9 \\
120 & 31.4 & 17 & 127.0 & 16.6 \\
\hline
\end{tabular}

Table 2 „Field read“ bean variety.

\begin{tabular}{ccccc}
\hline $\begin{array}{c}\text { Time, } \\
\text { sec }\end{array}$ & $\begin{array}{c}\text { Initial temperature, } \\
{ }^{\mathbf{0}} \mathbf{C}\end{array}$ & $\begin{array}{c}\text { Initial moisture content } \\
\mathbf{W \%}\end{array}$ & $\begin{array}{c}\text { Final temperature, } \\
\mathbf{0}^{\mathbf{C}} \mathbf{C}\end{array}$ & $\begin{array}{c}\text { Final moisture content, } \\
\mathbf{W \%}\end{array}$ \\
\hline 0 & 27.2 & 31.25 & 27.2 & 31.1 \\
30 & 28.1 & 29.8 & 65.1 & 25.8 \\
60 & 27.5 & 30.5 & 84.6 & 24.9 \\
90 & 26.8 & 30.2 & 98.1 & 24.2 \\
120 & 26.6 & 29.8 & 114.5 & 23.6 \\
\hline
\end{tabular}

Table 3 White lupin beans.

\begin{tabular}{ccccc}
\hline $\begin{array}{c}\text { Time, } \\
\text { sec }\end{array}$ & $\begin{array}{c}\text { Initial temperature, } \\
{ }^{\mathbf{0}} \mathbf{C}\end{array}$ & $\begin{array}{c}\text { Initial moisture content } \\
\mathbf{W , \%}\end{array}$ & $\begin{array}{c}\text { Final temperature, } \\
{ }^{\mathbf{0}} \mathbf{C}\end{array}$ & $\begin{array}{c}\text { Final moisture content, } \\
\mathbf{W} \%\end{array}$ \\
\hline 0 & 27.8 & 17.5 & 28.0 & 17.3 \\
30 & 27.9 & 19.6 & 78.2 & 16.4 \\
60 & 28.4 & 21.5 & 108.0 & 13.0 \\
90 & 27.8 & 24,5 & 109.7 & 13.3 \\
120 & 27.9 & 19.1 & 125.5 & 11.7 \\
\hline
\end{tabular}

The effects of changes in the structural characteristics of starch on mechanical and functional properties, as well as on the characteristics of the digestibility of starch were discussed. They attempted to present the theoretical foundations of the interaction of infrared radiation with grain and its components.

Micronization and pre germination of peas before milling resulted in changes to flour particle size, co $\neg$ lor, and compositional and functional properties of the flours. Peas tempered to $18 \%-20 \%$ and micronized to $105-110^{\circ} \mathrm{C}$ produced flour that was similar in baking properties to the flour milled from untre $\neg$ ated peas except for crumb firmness and aroma and flavor of the bread (Frohlich et al., 2019).

The authors (Deepa and Hebbar, 2017) evaluated the effectiveness of micronization of corn (Arjun, EH-434042) in inactivating enzymes respon $\neg$ sible for lipid breakdown and extending the shelf life of whole corn flour. Micronization at $200{ }^{\circ} \mathrm{C}$ for $4 \mathrm{~min}$ led to complete inactivation of the peroxidase enzyme and a decrease in lipase activity by $84 \%$. The results showed no significant change in the free fatty acid content of the micronized flour, whereas a significant increase was observed in the raw flour under both storage conditions. The color and carotenoid content of cornflour did not differ greatly during storage. Whereas micronized cornmeal was stored for 60 and 120 days under accelerated and ambient conditions, respectively, without significant impact on quality, the shelf life for raw cornmeal under similar conditions was only 15 and 30 days.

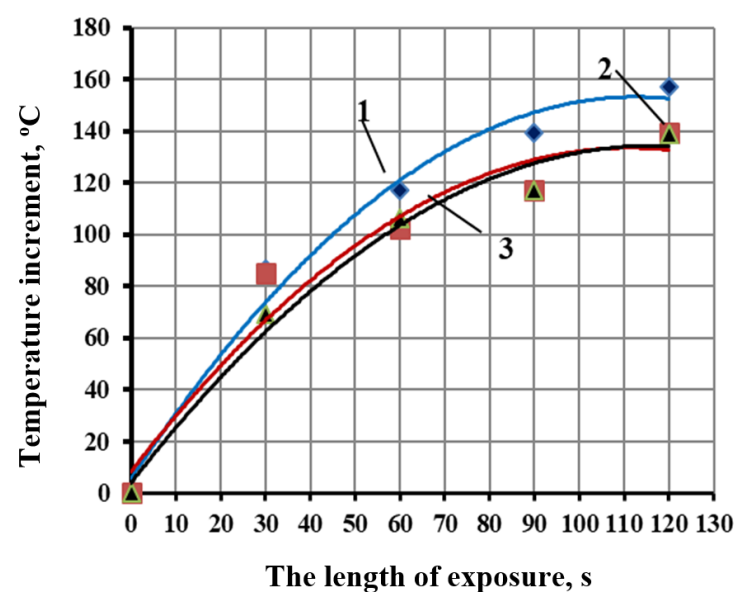

Figure 5 The influence of the length of exposure of IR heat treatment on the temperature increment of the sample weight of ,Tsanava“ bean variety at the height of $50 \mathrm{~mm}$ from the QP1 model emitters set to the pallet, with the initial average moisture contents, $\%: 1-12.7$; $2-17.7 ; 3-29.2$.

\section{Changes in the moisture content of bean during the IR heat treatment process}

The influence of the length of exposure of IR heat treatment on the moisture content of the sample weight of the „Tsanava“ bean variety at the different heights shown in Figure 6-8.

The results obtained are in good agreement with the results obtained for soybeans and cereals in the work Kozin (2011). 
The authors Campos-Vega et al. (2018) pay special attention to the post-harvest processing of dry beans necessary to ensure high-quality cooking, storage, and food safety. It also provides details on low-energy technologies as well as new processes for developing functional food ingredients from dry beans concerning composition and nutritional changes and their impact on human health and well-being.

\section{Process modeling during heat treatment A lumped model of heating}

As the simplest model, a first-order differential equation is used, reflecting the heat balance as a whole for the caryopsis, in the form as follows:

$$
\begin{aligned}
\operatorname{CMd}(\Delta \mathrm{T}) / \mathrm{dt} & =\mathrm{P}_{\mathrm{E}}+\mathrm{P}_{\mathrm{k}}-\mathrm{P}_{\mathrm{d}} \\
\Delta \mathrm{T} & =\mathrm{T}-\mathrm{T}_{0}
\end{aligned}
$$

Where:

$\mathrm{P}_{\mathrm{E}}$ - absorbed radiation power, $\mathrm{W} ; \mathrm{P}_{\mathrm{k}}-$ convective heat transfer power, $\mathrm{W} ; \mathrm{P}_{\mathrm{d}}-$ power spent on desorption of moisture (evaporation), $\mathrm{W} ; \mathrm{T}-$ the average current temperature, $\mathrm{K} ; \mathrm{T}_{0}$ - the initial temperature of the product and the ambient temperature, $\mathrm{K} ; \mathrm{C}$ - specific heat capacity, $\mathrm{J} . \mathrm{kg}^{-1} ; \mathrm{M}-$ the mass of caryopsis, $\mathrm{kg}$.

Radiation power absorbed by the product:

$$
P_{E}(t)=K_{s} S_{1} A E(t)
$$

Where:

$\mathrm{S}_{1}$ - the surface area of caryopsis, $\mathrm{m}^{2} ; \mathrm{A}$ - absorption factor; $\mathrm{K}_{\mathrm{S}}$ - coefficient of proportionality; $\mathrm{E}(\mathrm{t})$ - irradiance (a function of time in general), W. $\mathrm{m}^{-2} ; \mathrm{t}$ - treatment time, $\mathrm{s}$.

Convective heat transfer power with the environment:

$$
\begin{gathered}
\mathrm{Pk}^{\prime}=\mathrm{K}_{\alpha} \mathrm{S}_{1}\left[\Delta \mathrm{T}_{\mathrm{c}}(\mathrm{t})-\mathrm{K}_{\mathrm{g}} \Delta \mathrm{T}\right] \\
\Delta \mathrm{Tc}(\mathrm{t})=\mathrm{T}_{\mathrm{c}}(\mathrm{t})-\mathrm{T} 0
\end{gathered}
$$

Where:

$\mathrm{K}_{\alpha}$ - coefficient that takes account of heat exchange medium, W/K; Kg - coefficient that takes account of the difference between the average temperature and the temperature on the surface; $\mathrm{Tc}(\mathrm{t})$ - ambient temperature, ${ }^{\circ} \mathrm{C}$ (a function of time in general).

Power spent on desorption of moisture (evaporation):

$$
P_{d}=K_{d}(\lambda+\varepsilon / \mu) d m_{B} / d t
$$

Where:

$\mathrm{m}_{\mathrm{B}}$ - the mass of moisture, $\mathrm{kg} ; \lambda=(2.503-2.255) .10^{6}-$ the latent heat of free water evaporation, $\mathrm{J}_{\mathrm{kg}} \mathrm{kg}^{-1} ; \varepsilon$ - adsorption potential, J.mol ${ }^{-1} ; \mu=0,018-$ molar mass of vapor, kg.mol ${ }^{-}$ ${ }^{1} ; \mathrm{K}_{\mathrm{d}}-$ coefficient of proportionality.

In the general case, during the heating process, neither the mass of caryopsis $M$ (as a result of moisture evaporation), nor the heat capacity $\mathrm{C}$, nor the heat transfer coefficient $\mathrm{K}_{\alpha}$, nor the coefficient $\mathrm{Kg}$ remains constant due to their dependence on the current temperature and moisture content.

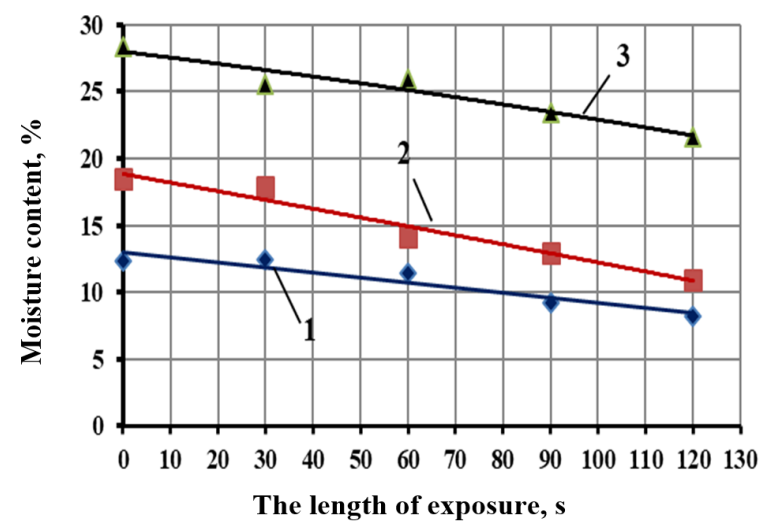

Figure 6 The influence of the length of exposure of IR heat treatment on the moisture content of the sample weight of ,Tsanava“ bean variety at the height of $100 \mathrm{~mm}$ from the QP1 model emitters set to the pallet, with the initial average moisture contents $1-12.7 ; 2-17.7$; $3-29.2$.

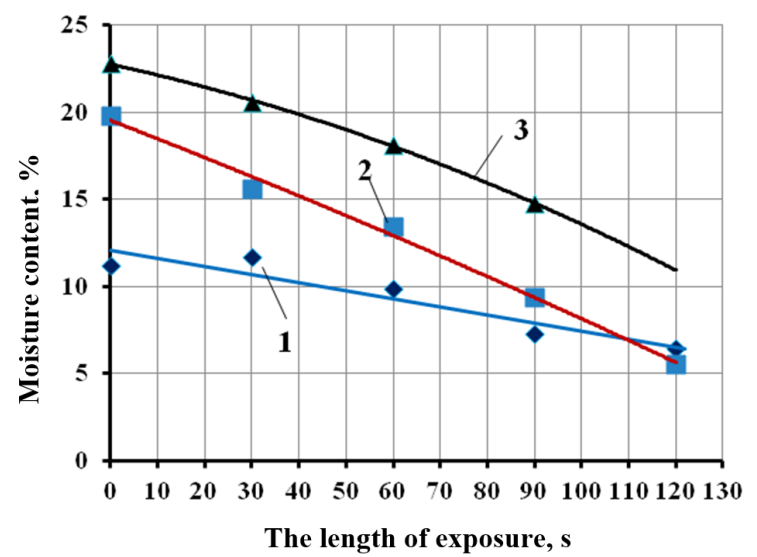

Figure 7 The influence of the length of exposure of IR heat treatment on the moisture content of the sample weight of „Tsanava“ bean variety at the height of $75 \mathrm{~mm}$ from the emitters' panel to the pallet, with the initial average moisture contents, $\% 1-12.7 ; 2-17.7 ; 3-29.2$.

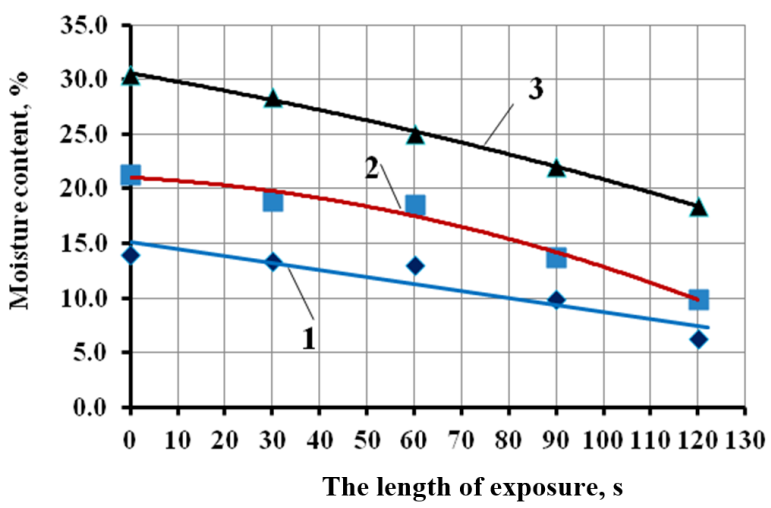

Figure 8 The influence of the length of exposure of IR heat treatment on the moisture content of the sample weight of „Tsanava“" bean variety at the height of $50 \mathrm{~mm}$ from the emitters' panel to the pallet, with the initial average moisture contents: $1-12.7 ; 2-17.7 ; 3-29.2$. 
The moisture content of the product undergoing treatment also affects the absorption factor A, with the adsorption potential $\varepsilon$.

The processes of heat and moisture exchange are interrelated and, in the general case, are described by a system of corresponding non-linear differential equations. Essentially, in the case of taking into account heat losses due to evaporation, and in the general case, other exothermic reactions as well, occurring when the product is heated, to determine the temperature in a function of time, it is necessary to solve the system of non-linear differential equations:

$$
\begin{gathered}
\mathrm{CMd}(\Delta \mathrm{T}) / \mathrm{dt}=\quad \mathrm{S}_{1}\left\{\mathrm{~K}_{\mathrm{s}} \mathrm{AE}(\mathrm{t})+\mathrm{K}_{\alpha}\left[\Delta \mathrm{T}_{\mathrm{c}}-\mathrm{K}_{\mathrm{g}} \Delta \mathrm{T}\right]\right. \\
\left.\mathrm{Kd}(\lambda+\varepsilon / \mu) \mathrm{dm}_{\mathrm{B}} / \mathrm{dt}\right\} \\
\mathrm{dm}_{\mathrm{B}} / \mathrm{dt}=-\mathrm{fW}_{\mathrm{W}}\left[\mathrm{T}(\mathrm{t}), \mathrm{m}_{\mathrm{B}}\right] \\
\mathrm{C}(\mathrm{T})\left[\mathrm{M}+\mathrm{m}_{\mathrm{B}}(\mathrm{t})\right] \mathrm{d}(\Delta \mathrm{T}) / \mathrm{dt}=\mathrm{S}_{1}\left\{\mathrm{~K}_{\mathrm{s}} \mathrm{AE}(\mathrm{t})+\mathrm{K}_{\alpha} \quad\left[\Delta \mathrm{T}_{\mathrm{c}}-\right.\right. \\
\left.\left.\mathrm{K}_{\mathrm{g}} \Delta \mathrm{T}\right]-\mathrm{Kd}(\lambda+\varepsilon / \mu) \mathrm{dm}_{\mathrm{B}} / \mathrm{dt}\right\} \\
\mathrm{dm}_{\mathrm{B}} / \mathrm{dt}=-\mathrm{W}\left[\mathrm{T}(\mathrm{t}), \mathrm{m}_{\mathrm{B}}\right]
\end{gathered}
$$$$
\mathrm{d}(\Delta \mathrm{T}) / \mathrm{dt}+\mathrm{S}_{1} \mathrm{~K}_{\alpha} \mathrm{Kg} \Delta \mathrm{T} / \mathrm{C}(\mathrm{T})\left[\mathrm{M}+\mathrm{m}_{\mathrm{B}}(\mathrm{t})\right]=\left\{\mathrm { S } _ { 1 } \left[\mathrm{K}_{\mathrm{s}} \mathrm{AE}(\mathrm{t})+\right.\right.
$$$$
\left.\left.\mathrm{K}_{\alpha} \Delta \mathrm{T}_{\mathrm{c}} \mathrm{T}-\mathrm{Kd}(\lambda+\varepsilon / \mu) \mathrm{dm}_{\mathrm{B}} / \mathrm{dt}\right]\right\} / \mathrm{C}(\mathrm{T})[\mathrm{M}+\mathrm{mB}(\mathrm{t})]
$$

The function $f_{W}\left[T(t), m_{B}\right]$ is non-linear and reflects the process of moisture evaporation. Usually, it is not possible to solve the system of equations (6) in an analytical form. The use of numerical methods is also practically impossible since the number of coefficients included in the equations is not determined. Therefore, we have to resort to various kinds of assumptions and simplifications, often rather rough ones.

Suppose that:

$$
\begin{array}{ccc}
\mathrm{S}_{1} \mathrm{~K}_{\alpha} \mathrm{Kg} / \mathrm{C}(\mathrm{T})\left[\mathrm{M}+\mathrm{m}_{\mathrm{B}}(\mathrm{t})\right]=\mathrm{Kt}=\mathrm{const}, \quad\left\{\mathrm { S } _ { 1 } \left[\mathrm{K}_{\mathrm{s}} \mathrm{AE}(\mathrm{t})+\right.\right. \\
\left.\left.\mathrm{K}_{\alpha} \Delta \mathrm{T}_{\mathrm{c}} \mathrm{T}-\mathrm{Kd}(\lambda+\varepsilon / \mu) \quad \mathrm{dm}_{\mathrm{B}} / \mathrm{dt}\right]\right\} / \mathrm{C}(\mathrm{T})\left[\mathrm{M}+\mathrm{m}_{\mathrm{B}}(\mathrm{t})\right]= \\
\mathrm{a}_{1}=\mathrm{const}
\end{array}
$$

Where:

$\Delta \mathrm{T}=\mathrm{T}-\mathrm{T}_{0}, \mathrm{~T}-$ temperature, ${ }^{\circ} \mathrm{C} ; \mathrm{T}_{0}-$ initial temperature, ${ }^{\circ} \mathrm{C} ; \mathrm{T}_{\infty}$ - temperature, ${ }^{\circ} \mathrm{C}$ when $\mathrm{t} \rightarrow \infty$; $\mathrm{t}$ - time, $\mathrm{s}$;

$$
\Delta \mathrm{T}_{\infty}=\mathrm{T}_{\infty}-\mathrm{T}_{0}
$$

In the case of the constancy of these quantities, we have for the initial conditions $\Delta \mathrm{T}(0)=0$, the model of heating can be represented as:

$$
\Delta \mathrm{T}(\mathrm{t})=\mathrm{K}_{0}\left[1-\exp \left(-\mathrm{K}_{\mathrm{t}} \mathrm{t}\right)\right]
$$

Or

$$
\mathrm{t}(\Delta \mathrm{T})=-\ln \left[1-\Delta \mathrm{T} / \mathrm{K}_{0}\right] / \mathrm{K}_{\mathrm{t}}
$$

Where:

$\mathrm{K}_{0}=\Delta \mathrm{T}_{\infty},{ }^{\circ} \mathrm{C}$ and $\mathrm{Kt}, \mathrm{c}^{-1}-$ the empirical coefficients.

The coefficients are taken as constant (independent of time), but dependent on the heating conditions (initial moisture content, irradiance, and the ambient temperature in the treatment zone). The condition of constancy (weak change) of the coefficients is not satisfied in the full temperature range. It is known from experiments that close to a product temperature of $100{ }^{\circ} \mathrm{C}$, intensive dehydration begins, and the rate of moisture loss sharply increases. Therefore, the proposed dependence can be considered to be an initial, rather rough approximation.

A similar solution can be obtained using the solution obtained by A.V. Lykov in the form of the exponential series, taking the first two terms (Lykov and Mikhailov, 1972)

$$
\Delta \mathrm{T} /\left(\mathrm{T}_{\infty}-\mathrm{T}_{0}\right)=1+\mathrm{a}_{1} \exp \left(-\mathrm{k}_{1} \mathrm{t}\right)+\mathrm{ai} \exp \left(-\mathrm{k}_{\mathrm{i}} \mathrm{t}\right)
$$

Where:

a and $\mathrm{k}$ are coefficients.

Note that when identifying the parameters of models (10) for the temperature increment and (11) for time, according to the same experimental data, the numerical values of $\mathrm{K}_{0}$ and $\mathrm{K}_{\mathrm{t}}$ in the expressions will differ.

\section{A model that takes account of the influence of moisture content}

Typically, in industrial HTM installations, the irradiance and the ambient temperature that characterize the energy activity of the medium, are derived from the design of the treatment zone and are constant. Treatment time and product moisture content are varying.

Taking into account the prevailing influence of moisture content on coefficient $\mathrm{K}_{0}$ the model (10) can be represented as:

$$
\begin{gathered}
\Delta T(t)=K_{0} W^{C}\left[1-\exp \left(-K_{t} t\right)\right] \\
\Delta T(t)=K_{0}(1-W)^{C}\left[1-\exp \left(-K_{t} t\right)\right] \\
\Delta T(t)=K_{0} W^{W}\left[1-\exp \left(-K_{t} t\right)\right]
\end{gathered}
$$

Where:

$\mathrm{C}$ - empirical coefficient; $\mathrm{W}-$ moisture content, $\%$.

\section{A model of dehydration}

The authors (Heydari, Kauldhar and Meda, 2020) present the characteristics of drying lentils using thin layer microwave drying with and without hot air pre-drying. The characteristics were evaluated in a laboratory microwave dryer. Drying experiments were carried out at 300 and 750 $\mathrm{W}$, and the pre-drying experiment was carried out at room temperature $\left(23^{\circ} \mathrm{C}\right)$. Of several thin-layer mathematical models evaluated using experimental data, Page's model was found to be the most appropriate model for predicting the drying process of lentils.

The authors (Deepa and Hebbar, 2016) note that when cereals/legumes with sufficient moisture are micronized, some beneficial changes are observed, such as partial gelatinization of starch, inactivation of enzymes that are responsible for degradation, and denaturation of antinutritional factors. Partial gelatinization due to micronization improves starch digestibility and palatability and shortens cooking time without significantly affecting other nutrients present in the beans. 
Table 4 The results of identification of coefficients of a model (13) for the „Tsanava“ bean variety.

\begin{tabular}{cccccc}
\hline $\begin{array}{c}\text { The distance } \\
\text { between the } \\
\text { emitter and } \\
\text { product, } \\
\text { H mm }\end{array}$ & $\begin{array}{c}\text { Initial moisture } \\
\text { content } \\
\mathbf{W} \%\end{array}$ & $\mathbf{K 0}$ & $\mathbf{K t}$ & $\mathbf{C}$ & $\begin{array}{c}\text { The squared } \\
\text { pair correlation } \\
\text { coefficient, } \\
\mathbf{R 2}\end{array}$ \\
\hline 100 & $13-24$ & 2602 & 0.0239 & -1.14 & 0.96 \\
75 & $11-23$ & 203 & 0.0184 & -0.182 & 0.96 \\
50 & $14-30$ & 282 & 0.0242 & -0.218 & 0.98 \\
\hline
\end{tabular}

Table 5 The results of identification of coefficients of a model (13) for the „field red“ bean variety.

\begin{tabular}{cccccc}
\hline $\begin{array}{c}\text { The distance } \\
\text { between the } \\
\text { emitter and } \\
\text { product, } \\
\mathbf{H ~ m m}\end{array}$ & $\begin{array}{c}\text { Initial moisture } \\
\text { content } \\
\mathbf{W}, \mathbf{\%}\end{array}$ & $\mathbf{K}_{\mathbf{0}}$ & $\mathbf{K}_{\mathbf{t}}$ & $\mathbf{C}$ & $\begin{array}{c}\text { The squared } \\
\text { pair correlation } \\
\text { coefficient, } \\
\mathbf{R}^{\mathbf{2}}\end{array}$ \\
\hline 100 & $17.5-35.5$ & 364 & 0.0126 & -0.31 & 0.93 \\
75 & $14.1-28.4$ & 192 & 0.0156 & -0.129 & 0.98 \\
50 & $10.5-29.6$ & 232 & 0.0237 & -0.159 & 0.98 \\
\hline
\end{tabular}

Table 6 The results of identification of coefficients of a model for (13) for lupin.

\begin{tabular}{ccccc}
\hline $\begin{array}{c}\text { The distance } \\
\text { between the emitter } \\
\text { and product, } \\
\mathbf{H ~} \text { mm }\end{array}$ & $\begin{array}{c}\text { Initial moisture } \\
\text { content } \\
\mathbf{W , \%}\end{array}$ & $\mathbf{K}_{\mathbf{0}}$ & $\mathbf{K}_{\mathbf{t}}$ & $\begin{array}{c}\text { The squared pair } \\
\text { correlation } \\
\text { coefficient, } \\
\mathbf{R}^{\mathbf{2}}\end{array}$ \\
\hline 100 & 11 & 143 & 0.0103 & 0.99 \\
& 20 & 101 & 0.0233 & 0.99 \\
75 & 24 & 84 & 0.0248 & 0.98 \\
& 11 & 157 & 0.0194 & 0.98 \\
50 & 17 & 130 & 0.0207 & 0.99 \\
& 34 & 128 & 0.0155 & 0.98 \\
& 13 & 160 & 0.0251 & 0.99 \\
& 20 & 144 & 0.0193 & 0.98 \\
\hline
\end{tabular}

Table 7 The results of identification of coefficients of a model for $(10)\left(\Delta \mathrm{T}(\mathrm{t})=\mathrm{K}_{0} \mathrm{~W}^{\mathrm{C}}\left[1-\exp \left(-\mathrm{K}_{\mathrm{t}} \mathrm{t}\right)\right]\right)$ for lupin.

\begin{tabular}{cccccc}
\hline $\begin{array}{c}\text { The distance } \\
\text { between the } \\
\text { emitter and } \\
\text { product, } \\
\text { H mm }\end{array}$ & $\begin{array}{c}\text { Initial moisture } \\
\text { content } \\
\mathbf{W , \%}\end{array}$ & $\mathbf{K}_{\mathbf{0}}$ & $\mathbf{K}_{\mathbf{t}}$ & $\mathbf{C}$ & $\begin{array}{c}\text { The squared } \\
\text { pair correlation } \\
\text { coefficient, } \\
\mathbf{R}^{\mathbf{2}}\end{array}$ \\
\hline 100 & $11-24$ & 142 & 0.0181 & -0.109 & 0.96 \\
75 & $11-34$ & 304 & 0.189 & -0.270 & 0.98 \\
50 & $13-28$ & 567 & 0.0208 & -0.465 & 0.98 \\
\hline
\end{tabular}

We shall use the relationship (12). We shall confine ourselves to the first approximation, which, after substituting the model for the heating time (10) and the transformations, leads to a model for the relative current moisture content, as a function of a temperature increment:

$$
\mathrm{U} / \mathrm{U}_{0}=\left(1-\Delta \mathrm{T} / \mathrm{k}_{0}\right)^{\mathrm{C}},
$$

Where:

$\Delta \mathrm{T}$ - temperature increment; $\mathrm{k}_{0}$ and $\mathrm{C}$ - empirical coefficients.

The value of the parameter $\mathrm{k} 0$ can be taken from the results of the identification of the heating model parameters or, just as the parameters B and C, may be identified by the results of dehydration experiments. Identification of the parameters
$\mathrm{B}$ and $\mathrm{C}$ by the results of the experiments with a wide variation in the initial moisture content, irradiance, and temperature in the treatment zone, has shown a dependence on the initial moisture content and the absence of correlation with heating modes.

As a result, a model is proposed

$$
\mathrm{U} / \mathrm{U}_{0}=\left(1-\Delta \mathrm{TU}_{0} / \mathrm{K}_{0}\right)^{\mathrm{C}}
$$

Where:

U0 - initial moisture content.

However, it should be borne in mind that this model describes adequately the process of dehydration to an extent limited by the upper-temperature value of grain not much more than $100^{\circ} \mathrm{C}$. 


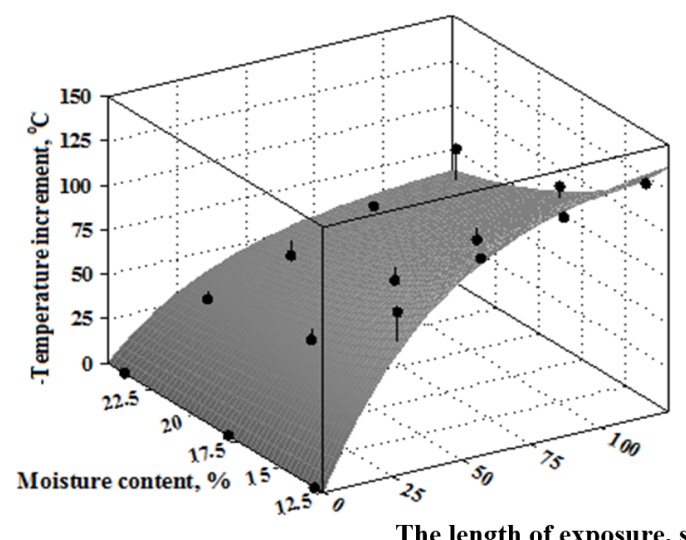

Figure 9 The „Tsanava“ bean: The height of the emitters panel $\mathrm{H}=100 \mathrm{~mm}$; Model $\Delta \mathrm{T}(\mathrm{t})=\mathrm{K}_{0} \mathrm{~W}^{\mathrm{C}}\left[1-\exp \left(-\mathrm{K}_{\mathrm{t}} \mathrm{t}\right)\right]$.

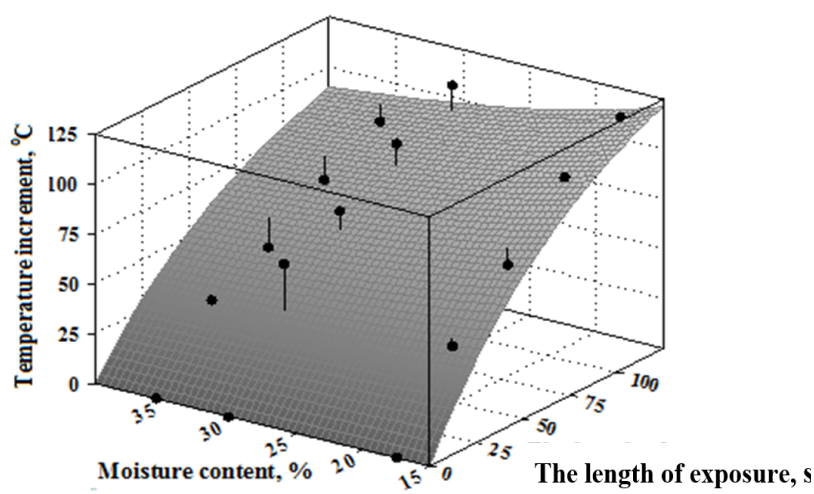

Figure 10 The ,field red" bean: The height of the emitters panel $\mathrm{H}=100 \mathrm{~mm}$; Model- $\Delta \mathrm{T}(\mathrm{t})=\mathrm{K}_{0} \mathrm{~W}^{\mathrm{C}}\left[1-\exp \left(-\mathrm{K}_{\mathrm{t}} \mathrm{t}\right)\right]$.

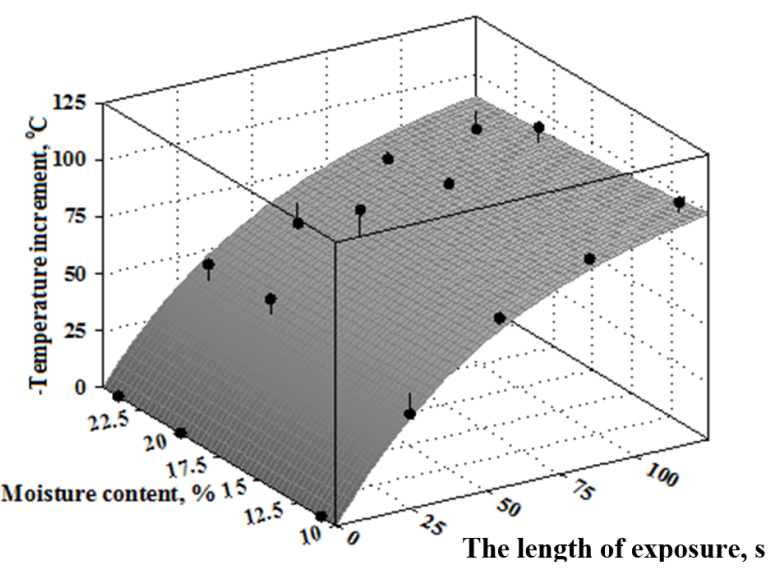

Figure 11 The ,White lupin“ beans: The height of the emitters panel $\mathrm{H}=100 \mathrm{Mm} ; \Delta \mathrm{T}(\mathrm{t})=\mathrm{K}_{0} \mathrm{~W}^{\mathrm{C}}\left[1-\exp \left(-\mathrm{K}_{\mathrm{t}} \mathrm{t}\right)\right]$.

From the presented graphs (Figure 6, Figure 7, and Figure 8 ) and earlier obtained results for barley and millet, it can be assumed that the model describes adequately experimental data on the small-sized $(3-5 \mathrm{~mm})$ objects.

As can be seen in Table 6 and Table 7, none of the models considered has any significant advantages. Hence, hereinafter, we will focus on the first of them.

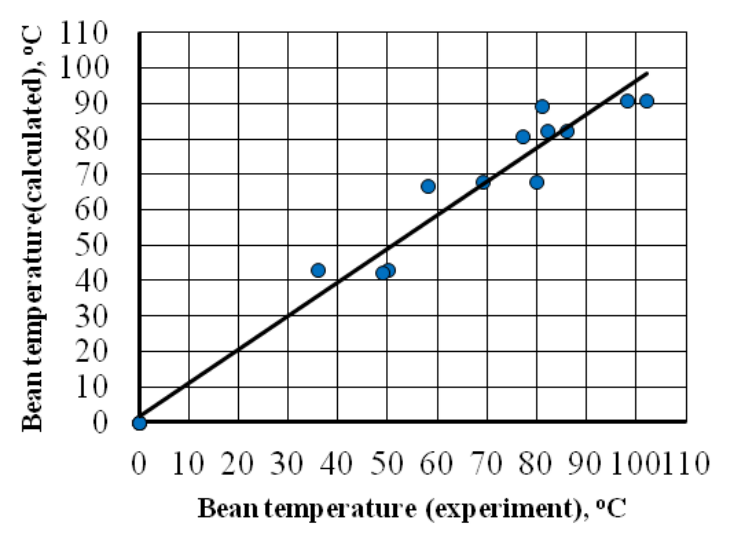

Figure 12 The height from the emitters' panel to the pallet, $\mathrm{H}=100 \mathrm{~mm}$.

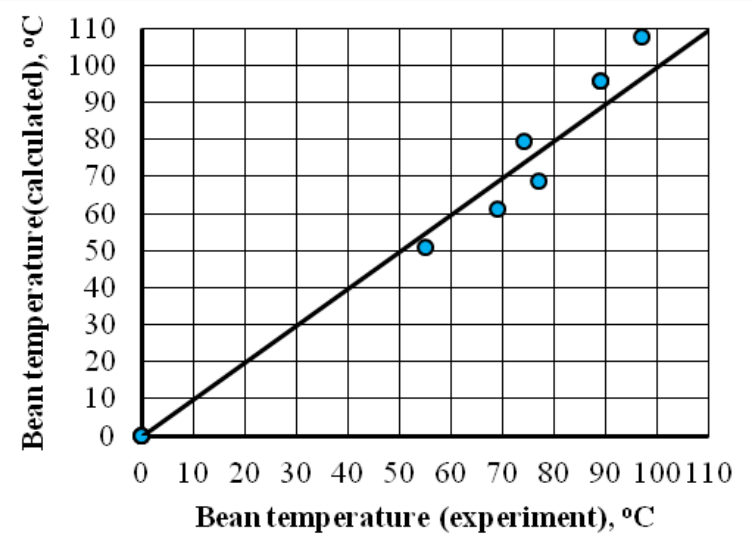

Figure 13 The height from the emitters' panel to the pallet, $\mathrm{H}=75 \mathrm{~mm}$,

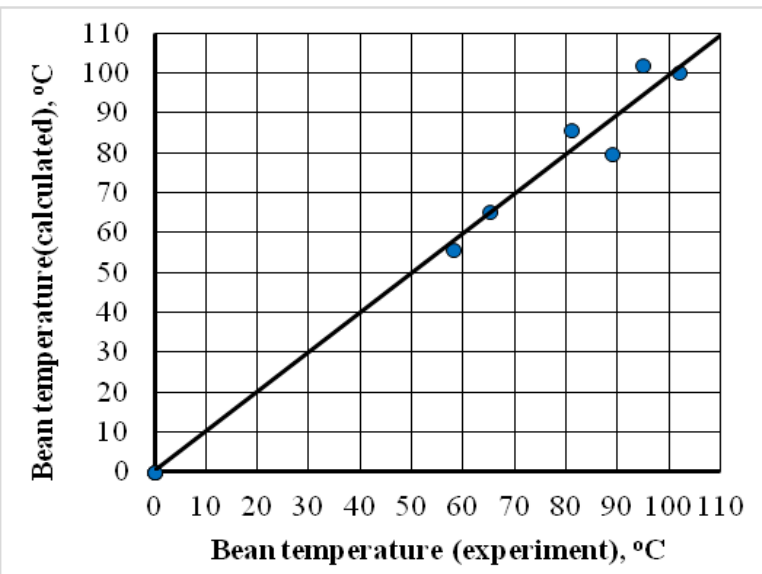

Figure 14 The height from the emitters' panel to the pallet, $\mathrm{H}=50 \mathrm{~mm}$.

Table 6 clearly shows the correlation $\mathrm{K}_{0}(\mathrm{~W})$. A similar effect was noted in the work (Zverev and Sesikashvili, 2016).

The results of experiments and calculations are shown in Figure 9, Figure 10, and Figure 11.

Based on the accepted theory, a program for calculating the basic quantities was designed using a mathematical 
package MathCad (Mathsoft, Cambridge, Massachusetts, USA) (Makarov, 2011).

The accuracy of temperature estimates according to the proposed model $\left(\mathrm{DT}(\mathrm{t})=\mathrm{K}_{0} \mathrm{WC}\left[1-\exp \left(-\mathrm{K}_{\mathrm{t}} \mathrm{t}\right)\right]\right.$ can be judged following Figure 12, Figure 13, and Figure 14.

As is seen in Figure 12, Figure 13, and Figure 14 the calculated temperature values are in satisfactory agreement with the experimental values.

\section{CONCLUSION}

Regardless of accepted assumptions, the models considered describe quite well the growth of the bean temperature during IR heating in the range of $30-100{ }^{\circ} \mathrm{C}$, at a higher moisture content.

An increase in the proportion of radiative heat input, due to a decrease in the distance between the radiator and the product's monolayer, leads to an increase in the irradiance and, consequently, to a reduction in the heating time to the setpoint temperature.

An increase in the initial moisture content of beans with unchanged other modes of HTM leads to an increase in temperature and, accordingly, to a reduction in the heating time to the fixed temperature. For a particular HTM installation, the proposed heating models allow to identify its coefficients through a series of simple experiments and then to use it for adjusting the heat treatment conditions.

\section{REFERENCES}

Arntfield, S. D., Scanlon, M., Malcolmson, L., Watts, B. M., Ryland, D., Savoie, V. 1997. Effect of tempering and end moisture content on the quality of micronized lentils. Food Research International, vol. 30, no. 5, p. 371-380. https://doi.org/10.1016/S0963-9969(97)00061-6

Campos-Vega, R., Bassinello, P. Z., de Andrade Cardoso Santiago, R., Oomah, B. D. 2018. Dry Beans: Processing and Nutritional Effects. In Grumezescu, A. M., Holban, A. M. Therapeutic, Probiotic and Unconventional Foods. Massachusetts, USA : Academic Press, p. 367-386. ISBN 9780-12-814625-5. https://doi.org/10.1016/B978-0-12-814625$\underline{5.00019-4}$

Deepa, C., Hebbar, H. U. 2016. Effect of High-Temperature Short-Time 'Micronization' of Grains on Product Quality and Cooking Characteristics. Food Engineering Reviews, vol. 8, p. 201-213. https://doi.org/10.1007/s12393-015-9132-0

Deepa, C., Hebbar, H. U. 2017. Effect of micronization of maize grains on shelf-life of flour. Food processing and preservation, vol 41, no. 5, p. 13-19 https://doi.org/10.1111/jfpp.13195

Erdoğdu, B. S., Ekiz, I. H., Erdoğdu, F., Atungulu, G. G., Pan, Z. 2011. Industrial applications of infrared radiation heating and economic benefits in food and agricultural processing. In Pan, Z., Atungulu, G. G. Infrared Heating for Food and Agricultural Processing, Food Science and Technology. Florida, USA : CRC Press, p. 237-274. ISBN 9780429150876.

Frohlich, P., Young, G., Bourré, L., Borsuk, Y., Sarkar, A., Sopiwnyk, E., Pickard, M., Dyck, A., Malcolmson, L. 2019. Effect of premilling treatments on the functional and breadbaking properties of whole yellow pea flour using micronization and pregermination. Cereal Chemistry, Cereals and grains association, vol. 96, no. 5, p. 895-907. https://doi.org/10.1002/cche.10193

GOST 13586.5. 2015. Grain. Method of moisture content determination.
Heydari, M. M., Kauldhar, B. S., Meda, V. 2020. Kinetics of a thin-layer microwave-assisted infrared drying of lentil seeds. Legume science, vol. 2, no. 2, p. 1-9. https://doi.org/10.1002/leg3.31

ISO 3166. 2015. Codes for the representation of names of countries and their subdivisions - Part 1: Country codes.

Kayitesi, E., Duodu, K., Minnaar, A., de Kock, H. D. 2013. Effect of micronisation of pre-conditioned cowpeas on cooking time and sensory properties of cooked cowpeas. Journal of the science of food and agriculture, vol. 93, no. 4, p. 838-845. https://doi.org/10.1002/jsfa.5805

Kozin, E. V. 2011. Termychesky aktiviruemie processi pri visokotemperaturnoi mikronizacii soevykh bobov, perlovoi krupi I prosa (Thermally activated processes during hightemperature micronization of soybeans and pearl barley and millet) : disertation theses. Moscow, p. 25. (in Russian)

Kulaychev, A. 1999. The complete works in three volumes, vol. 1. In Kulaychev, A. et al. Metodi I sredstva analiza dannikh v srede Windows STADIA-6 (Methods and tools of data analysis in a Windows environment STADIA-6). Information and computers, 344 p. ISBN 5-89-357-016-2. (in Russian)

Lee, E.-H. 2020. A Review on Applications of Infrared Heating for Food Processing in Comparison to Other Industries. In Knoerzer, K., Muthukumarappan, K. Innovative Food Processing Technologies. Amsterdam, Netherlands : Elsevier, 2480 p. ISBN 978-0-12-815782-4. https://doi.org/10.1016/B978-0-08-100596-5.22670-X

Lykov, A. V., Mikhailov, Y. A. 1972. Theory of heat and mass-transfer. University of Michigan, USA : Israel Program for Scientific Translations publishers, $558 \mathrm{p}$.

Makarov, E. 2011. Enzhinernie raschoty v Mathcad 15 (Engineering Calculations in Mathcad 15). Moskow-St. Petersburg, Piter, 404 p. ISBN 978-5-459-00357-4. (in Russian)

Niu, Z. Y., Classen, H. L., Scott, T. A. 2003. Effects of micronization, temperin and flaking on the chemical characteristics of wheat and its feeding value for broiler chicks. Canadian Journal of Animal Science, vol 83, p. 113-121. https://doi.org/10.1139/CJAS-2020-0025

Ogundele, O. M., Kayitesi, E. 2019. Influence of infrared heating processing technology on the cook-ing characteristics and functionality of African legumes. Journal of Food Science and Technology, vol. 56, p. 1669-1682. https://doi.org/10.1007/s13197-019-03661-5

Pan, Z., Atungalu, G. G. 2010. Infrared Heating for Food and Agricultural processing. Boca Raton, Florida, US : CRC Press. 300 p. ISBN-13 9781420090970.

Pan, Z., Li, X. 2014. Infrared Heating. In Sun, D-W. Emerging Technologies for Food Processing. $2^{\text {nd }}$ ed. Massachusetts, USA : Academic Press, 666 p. ISBN 9780124104815.

Pan, Z., Venkitasamy, C., Li, X. 2016. Infrared Processing of Foods. In Jayabalan, R., Malbaša, R., Sathishkumar, M. Reference Module in Food Science. Amsterdam, Netherlands : Elsevier, p. 1-12. ISBN 978-0-08-100596-5. https://doi.org/10.1016/B978-0-08-100596-5.03105-X

Perez-Maldonado, A. P. F. M., Farell, D. J. 2002. Effects of heat treatment on the inhibitor activity. British Poultry Science, vol .44, no. 2, p. 299-308. https://doi.org/10.1080/0007166031000085463

Rogov, Y. A., Nekrutman, S. V. 1986. Ultravisokochastotniy nagrev pishi (Ultra high frequency heating of food). Moskow, Russia : Agropromizdat Publishers, 286 p. (in Russian)

Sakare, P., Prasad, N., Thombare, N. Singh, R., Sharma, S. C. 2020. Infrared Drying of Food Materials: Recent Advances. 
Food Engineering Reviews, vol. 12, no. 3, p. 381-398. https://doi.org/10.1007/s12393-020-09237-w

Semwal, J., Meera, M. S. 2020. Infrared radiation: Impact on physicochemical and functional charac-teristics of grain starch. Starch: Biosinthesis, Nutrition, Biomedical, vol. 9, no. 1, p. 1622. https://doi.org/10.1002/star.202000112

Shershunov, V. A., Cherviakov, A. V., Kurzenkov, C. V. 2004. Sostoianie $i$ perspektivi ispolzovania novikh resursosberegaiushikh tekhnologii v proizvodstve kormov dlia zhivotnikh (State and prospects for the use of new resourcesaving technologies in the production of animal feed). Moskow, Russia : Nine print publishers, p. 136. ISBN 9781627796378. (in Russian)

Shulaev, G., Betin, A. 2010. Mikronizirovannaia soya dlia molodikh svinei (Micronized soybeans in young pig feed). Kombikorma, vol. 2, p. 76-80. (in Russian)

Shurchkova, Y. A., Ganzenko, V. V., Radchenko, N. L. 2007. Ekstruzionnie protsessi soevikh bobov (Extrusion processing of soybean grain). Storage and processing of grain, vol. 9, no. 99, p. 51-53. (in Russian)

Tuśnio, A., Barszcz, M., Święch, E., Skomiał, J., Taciak, M. 2020. Large intestine morphology and microflora activity in piglets fed diets with two levels of raw or micronized blue sweet lupin seeds. Livestock Science, vol. 240, p. 104137. https://doi.org/10.1016/j.livsci.2020.104137

Vaidyanathan, J. S., Krishnamurthy, K. 2020. Infrared heating for Decontamination. In Knoerzer, K., Muthukumarappan, K. Innovative Food Processing Technologies. Amsterdam, Netherlands : Elsevier, p. 501-506. ISBN 978-0-12-815782-4. https://doi.org/10.1016/B978-0-12815781-7.22348-2

Zverev, S. V. 2009. Visokotemperaturnaia mikronizacia $v$ proizvodstve zernoproduktov (High-temperature micronzation in production of cereal products). Moskow, Russia : Deli Print publishers, 222 p. ISBN 978-5-94343-202-6. (in Russian)

Zverev, S., Sesikashvili, O. 2016. Pervichnaia pererabotka zeren belogo lupina (Primary processing of grain white lupine). Kutaisi, Georgia : ATSU, 82 p. ISBN 978-9941-41796-2. (in Russian)

Zverev, S., Sesikashvili, O. 2018. Heating and dehydration of grain and cereals at a combined energy supply. Potravinarstvo Slovak Journal of Food Sciences, vol. 12, 2018, no. 1, p. 79-90. https://doi.org/10.5219/840

Zverev, S., Sesikashvili, O. 2018. Modeling of urease thermal inactivation processes in soybean at high-temperature micronization. Potravinarstvo Slovak Journal of Food Sciences, vol. 12, no. 1, p. 512-519. https://doi.org/10.5219/940

Zverev, S., Sesikashvili, O., Bulakh, Y. 2017. Soya. Pererabotka i primenenie (Soy. Processing and application). EU : Lambert Academic Publishing, 153 p. ISBN 978-613-818491-1. (in Russian)

Zverev, S. V., Kozin, E. V. 2008. Inaktivatsia ureazi vo vremia HTM soy (Inactivation of urease during HTM soy). Storage and processing of agricultural raw materials, vol. 4, p. 165-169. (in Russian)

Zverev, S. V., Zvereva, N. S. 2006. Funktsionalnie zernovie produkty (Functional grain products). Moskow, Russia : Deli Print publishers, 118 p. ISBN 5-94343-106-3. (in Russian)
Žilić, S., Šukalović, V., Milašinović-Šeremešić, M., Ignjatovic-Micic, D., Maksimovic, M., Nikolić, V. 2009. Effect of Micronisation on the Composition and Properties of the Flour from White, Yellow and Red Maize. Food Technol. Biotechnol., vol. 48, no. 2, p. 198-206.

\section{Funds:}

This work was supported by Shota Rustaveli National Science Foundation of Georgia (SRNSFG) grant FR-198531 "Studying the Process of Obtaining Foods with Increased Nutri $\neg$ tion Value from Some Leguminous Crops by Method of High-Temperature Micronization “.

\section{Acknowledgments:}

This article was written based on consultations provided by Sergey Zverev, Dr.T.Sn, Professor, Leading Researcher of Federal State Budgetary Scientific Institution "The AllRussian Research Institute of Grain and its Processing Products".

\section{Conflict of Interest:}

The authors declare no conflict of interest.

\section{Ethical Statement:}

This article does not contain any studies that would require an ethical statement.

\section{Contact Address:}

*Otari Sesikashvili, Akaki Tsereteli State University, Faculty of Engineering - Technical, Department of Mechanical engineering, Tamar - Mepe str. 59, 4600 Kutaisi, Georgia, Tel: +995 5939662 42,

E-mail: otar.sesikashvili@atsu.edu.ge

ORCID: https://orcid.org/0000-0003-1229-4141

Nodari Mardaleishvili, Akaki Tsereteli State University, Faculty of Engineering-Technical, Department of Mechanical engineering, Tamar - Mepe str. 59, 4600 Kutaisi, Georgia, Tel: +995 558368022 ,

E-mail: nodar.mardaleishvili@atsu.edu.ge

ORCID: https://orcid.org/0000-0001-6785-2505

Elene Gamkrelidze, Akaki Tsereteli State University, Faculty of Engineering-Technological, Department of Chemical technology and Ecology, Tamar - Mepe str. 59, 4600 Kutaisi, Georgia, Tel: +995 593352781,

E-mail: elene.gamkrelidze@atsu.edu.ge

ORCID: https://orcid.org/0000-0002-0196-9505

Shalva Tsagareishvili, LTD „Kutaisi 2021“, Manager. Nikea str. 1 Lane, 4, 4600 Kutaisi, Georgia, Tel: +995 596 444450 ,

E-mail: shakocagareishvili@mail.ru

ORCID: https://orcid.org/0000-0002-9347-6205

Corresponding author: * 